\title{
COMMENT
}

\section{ENJOINING STATE COURT PROCEEDINGS WHICH INTERFERE WITH NATIONAL LABOR POLICY}

The need to avoid friction and to preserve the integrity of the state judiciary has led to limitations on the federal power to enjoin proceedings in state courts. ${ }^{1}$ These limitations are presently embodied in 28 U.S.C. $\$ 2283$ (1964) :
A court of the United States may not grant an injunction to stay proceedings in a state court except as expressly authorized by Act of Congress, or where necessary in aid of its juris- diction, or to protect or effectuate its judgments. ${ }^{2}$

Interpretation of section 2283 was at issue in the recent case of NLRB v. Schertzer. ${ }^{3}$ The National Labor Relations Board had ordered an employer to pay back wages to an employee in settlement of an unfair labor practice dispute. ${ }^{4}$ After the Board issued its order, a creditor of the employee instituted garnishment proceedings in state court and named the employer as garnishee. Thereupon, the Board sought enforcement of the back-pay order in the Court of Appeals for the Second Circuit-despite the employer's avowed willingness to comply with the order 5 - and simultaneously petitioned that court for a stay of the state proceedings. The Second Circuit held that it had the power to grant the injunction-pursuant to section 2283- "in aid of its jurisdiction" and to "protect and effectuate its judgments," 6 and that in view of the threat that the state garnishment posed to the Board's administrative procedures, it would exercise its discretionary power and grant the Board's petition.

The "in aid of jurisdiction" exception, the first ground relied upon by the court in Schertzer, can be traced back to the Judiciary Act of 1793, which provided that no writs "of injunction [shall] be granted

1 See, e.g., Toucey v. New York Life Ins. Co., 314 U.S. 118 (1941).

2 The injunction is directed against the plaintiff in the state court, and not against the court itself. See, e.g., Sperry Rand Corp. v. Rothlein, 288 F.2d 245, 247 (2d Cir. 1961), and cases cited therein.

3360 F.2d 152 (2d Cir. 1966).

4154 N.L.R.B. 938 (1965). The procedure for payment of the back-pay award is for the employer to write a check to the employee and then to turn the check over to the regional office of the NLRB for disbursement. KAMmrolz \& McGuINEss, Practice and Procedure Before the National Labor Relations Board 75 (1962). 5360 F.2d at 153.

(Ibid.; accord, NLRB v. Ozanne, Inc., 307 F.2d 80 (1st Cir. 1962) (per curiam) ; NLRB v. Stackpole Carbon Co., 128 F.2d 188, 191-92 (3d Cir. 1942); NLRB v. Sunshine Mining Co., 125 F.2d 757, 762 (9th Cir. 1942). 
to stay proceedings in any court of a state." 7 Although this section, without substantial modification, remained in effect until the passage of the Judicial Code in $1948,{ }^{8}$ federal courts in the post-Civil War period experienced difficulty with the inflexibility of the standard and therefore carved exceptions. ${ }^{9}$ The first such case was French $v . H a y,{ }^{10}$ where a Virginia plaintiff sued a Pennsylvania defendant in a Virginia state court, alleging misappropriation of his property and demanding damages and an accounting. The suit for an accounting was removed to federal court before the state court had acted upon it, and a state decree which awarded the plaintiff damages was vacated by the federal court. Thereupon, the plaintiff brought an action in the Pennsylvania state court upon the vacated judgment, and the federal court enjoined the Pennsylvania court from holding further proceedings on the matter. The Supreme Court affirmed the injunction, holding that "while the jurisdiction [of the federal court] lasted it was exclusive, and could not be trenched upon by any other tribunal." 11 The state action had this effect because it would have deprived the federal court of the ability to grant an effective remedy in that a federal decree in favor of the defendant, without the stay, would leave him "in exactly the same situation he would have been if those decrees had been against him." ${ }^{12}$ Similarly, in Julian v. Central Trust Co., ${ }^{13}$ a federal court enjoined a state court from levying upon property involved in a foreclosure proceeding in the federal court because the state action would have deprived the federal court of the ability to make whatever disposition of the property it saw fit. ${ }^{14}$ These exceptions are presently included within the "in aid of jurisdiction" exception, ${ }^{15}$ and thus, under that

7 Act of March 2, 1793, § 5, 1 Stat. 335.

8 Section 5 of the Judiciary Act of 1793 was codified in Rev. Srat. \$720 (1875). At that time an exception was added to permit stays of state proceedings where the action arose under federal bankruptcy laws. Toucey v. New York Life Ins. Co., 314 U.S. 118, 132-33 (1941). Later $\$ 720$ was reenacted as $\$ 265$ of the Judicial Code of 1911. Act of March 3, 1911, \$265, 36 Stat. 1162.

${ }^{9}$ Durfee \& Sloss, Federal Injunctions Against Proceedings in State Courts: The Life History of a Statute, 30 MICE. L. REv. 1145, 1149 (1932).

1089 U.S. (22 Wall.) 250 (1874). For other examples, see Looney v. Eastern Texas R.R., 247 U.S. 214 (1918); Riverdale Cotton Mills Co. v. Alabama \& Ga. Mfg. Co., 198 U.S. 188 (1905); Julian v. Central Trust Co., 193 U.S. 93 (1904); Deitzsch v. Huidekoper, 103 U.S. 494 (1880). For an excellent discussion of French v. Hay, see Durfee \& Sloss, supra note 9, at 1149-51.

11 French v. Hay, 89 U.S. (22 Wall.) 250, 253 (1874).

12 Ibid.

13193 U.S. 93 (1904).

14 Id. at 112-14. The general rule under the pre-section 2283 anti-injunction statutes was that "when a federal court has acquired jurisdiction, whether originally or by removal, . . . it may enjoin proceedings in a state court for the incidental purpose of making effective its 'prior jurisdiction ... .' Durfee \& Sloss, supra note 9 , at 1151 . It is doubtful whether this doctrine permitted a stay of the state proceedings where the only objection was that the state court and the federal court had concurrent in personam jurisdiction. See Note, Federal Power to Enjoin State Coutr Proceedings, 74 HARV. L. REv. 726, 731-32 (1961).

$\mathbf{1 5}$ The Revisers' Notes to $\$ 2283$ indicate that the "in aid of jurisdiction" exception was intended to include the removal exception. H.R. REP. No. 308, 80th 
clause, a federal court may enjoin state proceedings which frustrate its ability to grant an appropriate remedy.

The leading case illustrating the application of the "in aid of jurisdiction" exception is Capital Service, Inc. v. NLRB. ${ }^{16}$ In that case, an employer filed an unfair labor practice charge with the Board and simultaneously petitioned a state court to enjoin a labor union from picketing. The state court issued an injunction, and the NLRB petitioned the federal district court, pursuant to section $10(\mathrm{j})$ of the National Labor Relations Act, ${ }^{17}$ to enjoin the picketing and to stay the state injunction proceedings on the ground that the stay was necessary to preserve the federal court's jurisdiction over the injunction proceedings. The district court granted the stay as necessary "in aid of its jurisdiction," and the Supreme Court affirmed, holding that the district court must "have unfettered power to decide for or against the union, and to write such decree as it deemed necessary to effectuate the policies of the Act . . . "18 Thus the district court could stay the state proceedings to free itself of the remedial restraints which the state court had imposed.

In Schertzer, unlike Capital Service, there was no remedial conflict between the state garnishment action and enforcement of the back-pay award against the avowedly willing employer, and therefore the "in aid of jurisdiction" exception employed by the court was inapposite. ${ }^{19}$ State garnishment does not release the employer from his economic obligation and thereby permit him to retain the fruits of his unlawful conduct, nor is the employee deprived of the compensation which the Board and the court have awarded him. The employee will receive the money or its value in any case, either by the extinguishment of an existing debt or in cash, if upon final adjudication the state court finds that the creditor does not have a valid claim. The only change in the situation is of a purely technical nature, i.e., the back-pay award is made subject to the creditor's remedies which would attach to any of the

Cong., 1st Sess. A 181-82 (1947) ; accord, Structural Steel \& Forge Co. v. Union Pac. R.R., 269 F.2d 714 (10th Cir.), cert. denied, 361 U.S. 886 (1959). The "in rem" exception, exemplified by Julian v. Central Trust Co., 193 U.S. 93 (1904), was likewise included. Jacksonville Blow Pipe Co. v. Reconstruction Fin. Corp., 244 F.2d 394 (5th Cir. 1957) (alternate holding).

16347 U.S. 501 (1954). In this case, as in Schertzer, the type of jurisdiction under discussion is the subject-matter jurisdiction conferred by the NLRA.

1761 Stat. 149 (1947), 29 U.S.C. $\$ 160(j)$ (1964). Section 10(j) provides, in relevant part: "The Board shall have power, upon issuance of a complaint .. . charging that any person has engaged in or is engaging in an unfair labor practice, to petition any United States district court . . . for appropriate temporary relief or restraining order."

18347 U.S. at 505-06.

19 The discussion assumes that the court of appeals will enforce the Board's order since the employer did not contest the back-pay award. However, if for some reason the court of appeals refused to enforce the Board's order, obviously there is no longer a debt subject to garnishment and therefore the impossibility of conflict between the federal and state judiciaries is even clearer. 
employee's property in the state. ${ }^{20}$ In no sense can this change be deemed to be of such magnitude as to deprive the federal court of jurisdiction. Indeed, the whole issue is somewhat academic since not even the Board contends that the creditor could not sue the employee directly after he has received the money. Thus under the facts of Schertzer, the "in aid of jurisdiction" exception cannot justify the stay of the state garnishment proceedings.

The third exception to section 2283-to "protect or effectuate" the judgments of a federal court-is directed to the specific problem of state court relitigation of matters previously adjudicated by the federal courts. ${ }^{21}$ Thus a state court may be enjoined from overturning a federal judgment. This exception, despite the Second Circuit's invocation of the appropriate language, is inapplicable to Schertaer because in that case the federal court had not yet rendered a judgment. ${ }^{22}$ If the court meant only to protect judgments which it might choose to render, the considerations are identical to those discussed above under the "in aid of jurisdiction" exception.

Thus neither of the grounds given by the court justify the result in Schertzer. Under section 2283, however, there is one additional ground for granting a stay of state court proceedings-an express congressional authorization. While the National Labor Relations Act does not expressly authorize the district courts or the courts of appeals to enjoin state proceedings, the absence of such language does not necessarily mean that this exception is inapplicable. ${ }^{23}$ Prior to the enactment of section 2283, many acts of Congress were interpreted by the courts as implied authorizations for staying state proceedings, ${ }^{24}$ and the express authorization exception, despite the obvious clarity of the language, embodies these implied exceptions. ${ }^{25}$ For example, the

20 Generally speaking, it is one of the policies of the National Labor Relations Act . . to require an employer to compensate employees in money for any loss in wages suffered by them as a result of any one or more of the defined unfair labor practices. It is the policy of Massachusetts, evidently, to subject wages above a fixed minimum sum and subject to the safeguard of judicial scrutiny, to the payment of a wage earner's just debts. . . We see no necessary collision between these policies nor have we heard any cogent reason advanced by the Board why this Court should grant the relief which it seeks to protect an alleged debtor-employee from the operation of the state policy.

NLRB v. Underwood Machinery Co., 198 F.2d 93, 95 (1st Cir. 1952), overruled, NLRB v. Ozanne, Inc., 307 F.2d 80 (1st Cir. 1962) (per curiam).

21 Reviser's Notes, H.R. Rep. No. 308, 80th Cong., 1st Sess. A 181-82 (1947); accord, Jackson v. Carter Oil Co., 179 F.2d 524 (10th Cir. 1950).

22360 F.2d at 153.

23 Amalgamated Clothing Workers v. Richman Bros. Co., 348 U.S. 511, 516 (1955) (dictum).

24 See generally Comment, Injunction by Federal Court Against State Court Interference With NLRB Back Pay Order, 52 Y ALE L.J. 150 (1942); Note, Federal Power to Enjoin State Court Proceedings, 74 HARv. L. Rev. 726, 730-31 (1961).

25 Revisers' Notes, H.R. REp. No. 308, 80th Cong., 1st Sess. A 181-82 (1947) ; accord, Amalgamated Clothing Workers v. Richmond Bros. Co., 348 U.S. 511, 514 (1955). See generally Note, Incompatibility-the Touchstone of Section $2283^{\prime}$ s Express Authorization Exception, 50 VA. L. REv. 1404, 1408-14 (1964). 
Frazier-Lemke Act of $1933{ }^{26}$ provided that once a farmer had filed a bankruptcy petition in federal court, the farmer and his property shall be subject to the "exclusive jurisdiction of the court," and that proceedings with respect to that adjudication shall not be maintained in any other tribunal. There was no express provision for an injunction; ${ }^{27}$ nonetheless, it is clear that the act operated as an implied exception. As the Supreme Court stated in Kalb v. Feuerstein ${ }^{28}$ :

If Congress has vested in the bankruptcy courts exclusive jurisdiction over farmer-debtors and their property, and . . . withdrawn [it] from all other courts . . . its Act is the supreme law of the land which all courts-state and federalmust observe. The wisdom and desirability of an automatic statutory ouster of jurisdiction . . . were considerations for Congress alone. ${ }^{29}$

Similarly, the Shipowners Act of $1851^{30}$ provides only that once a shipowner deposits with the court a sum equal to the value of his interest in the ship, "all claims and proceedings against the owner with respect to the matter in question shall cease." This clause has been held to authorize, by implication, a stay of state proceedings. ${ }^{31}$

Clearly the National Labor Relations Act does not present as strong a case for finding an implied exception as do the above statutes. The NLRA does not expressly prohibit proceedings in other tribunals once the court of appeals has taken jurisdiction for enforcement ${ }^{32}$ or review ${ }^{33}$ of a Board order, or once the district court has taken jurisdiction of a proceeding for a temporary injunction. ${ }^{34}$ The NLRA does provide, however, that only the federal district courts may

2647 Stat. 1473.

27 An express provision was later added. 49 Stat. 944 (1935), as amended, 11 U.S.C. $\$ 203(\mathrm{~s})(2)$ (1958). Although there are no cases after the adoption of $\$ 2283$ in 1948, it would seem that the exception survived. Note, Incompatibility-the Touchstone of Section 2283's Express Authorization Exception, 50 VA. L. REv. 1404, 1409 (1964). See Revisers' Notes, H.R. REP. No. 308, 80th Cong., 1st Sess. A 181-82 (1947).

$$
28308 \text { U.S. } 433 \text { (1940). }
$$

29 Id. at 439 (dictum).

309 Stat. 635, as amended, 46 U.S.C. $\$ 185$ (1964).

31 Beal v. Waltz, 309 F.2d 721, 724 (5th Cir. 1962).

32 Section 10(e), 61 Stat. 147 (1947), 29 U.S.C. $\$ 160$ (e) (1964) :

The Board shall have power to petition any court of appeals of the United States ... for the enforcement of such order .... Upon the filing of such petition, the court . . shall have jurisdiction of the proceeding . . . [T] je jurisdiction of the court shall be exclusive . . . 33 Section 10(f), 61 Stat. 148 (1947), 29 U.S.C. $\$ 160(f)$ (1964):

Any person aggrieved by a final order of the Board . . . may obtain a review of such order in any United States court of appeals . . . Upon the filing of such petition, the court shall proceed in the same manner as in the case of an application by the Board under subsection (e) of this section, and shall have the same jurisdiction . . . supra.

34 Section 10(j), 61 Stat. 149 (1947), 29 U.S.C. \$160(j) (1964). See note 17 
consider Board petitions for a temporary restraining order, ${ }^{35}$ and that the jurisdiction of the courts of appeals for review and enforcement "shall be exclusive." ${ }^{36}$ Thus preemption would seem to provide a rational ground for implying an exception to the general rule of section 2283.

In Amalgamated Clothing Workers v. Richman Bros. Co. ${ }^{37}$ however, the Supreme Court rejected the position that preemption impliedly authorized federal courts to enjoin state proceedings. ${ }^{38}$ In Richman, an employer brought an action in state court to enjoin a union from picketing, and neither he nor any other interested party filed an unfair labor practice charge with the Board. The state court enjoined the picketing despite the union's objection that, under the NLRA, only the Board could seek such relief, and only in a federal court. The union, therefore, with the Board filing a brief as amicus curiae, brought an action in the district court to enjoin the state proceedings, urging preemption. The district court refused to grant the injunction, and the Supreme Court affirmed. Mr. Justice Frankfurter, writing for the majority, recognized that the real issue in the case was not protection of the district court's jurisdiction but protection of the prospective jurisdiction of the Board. ${ }^{39}$ Nonetheless, the Court held, in effect, that preemption as an implied authorization for a stay of state proceedings was not the method Congress had prescribed for protecting the Board's jurisdiction. ${ }^{40}$ Mr. Justice Frankfurter reasoned that the preemption argument was based on the fallacious assumption that Congress intended to authorize injunctions because the state courts could not adequately protect federal rights, and that judicial history clearly demonstrated that state courts, subject to review by the Supreme Court, were perfectly competent to vindicate federal rights. ${ }^{41}$ This being so, a stay of state proceedings would

35 Ibid.

36 Section 10(e), 61 Stat. 147 (1947), 29 U.S.C. $\$ 160(e)$ (1964). See notes $32 \& 33$ sipra.

37348 U.S. 511 (1955).

38 Id. at 515; accord, T. Smith \& Son v. Williams, 275 F.2d 397 (5th Cir. 1960); H. J. Heinz Co. v. Owens, 189 F.2d 505 (9th Cir. 1951), cert. denied, 342 U.S. 905 (1952); International Union of Operating Eng'rs v. William D. Baker Co., 100 F. Supp. 773 (E.D. Pa. 1951).

39348 U.S. at 520 .

40 In Bowles v. Willingham, 321 U.S. 503 (1944), a case arising under the Emergency Price Control Act, 56 Stat. 23 (1942), the Supreme Court upheld the issuance of a stay of state proceedings on the ground that the EPCA preempted the dispute that was being adjudicated in the state court. Bozvles, however, seems distinguishable from Richman because in Bowles a complaint was filed with the Price Administrator who was thus able to impart jurisdiction to the federal district court by petitioning for an injunction to restrain Mrs. Willingham from violating the EPCA. Section 205(a), 56 Stat. 33 (1942). Conversely, in Richman no charge was ever filed with the Board, and therefore it was powerless to bring the dispute before the federal courts. Had the Board in Richman been able to invoke the jurisdiction of a federal court, the Board could have secured the relief which the union failed to obtain. Capital Service, Inc. v. NLRB, 347 U.S. 501 (1954).

41348 U.S. at 518. 
create the friction and discord which section 2283 was designed to avoid without any concomitant benefit. Section 2283, therefore, should be interpreted narrowly and "not [as] a statute . . . conveying a broad general policy for appropriate ad hoc application." 42

In Richman, Mr. Justice Frankfurter stated that although the preemption argument could not be used to protect the Board's jurisdiction, the Board could utilize the Capital Service technique. ${ }^{43}$ That is, where the Board can impart jurisdiction to a federal court under either section $10(\mathrm{e})$ or section $10(\mathrm{j})$ of the NLRA, it may petition that court for a stay of state proceedings on the ground that it is necessary in aid of the court's jurisdiction. ${ }^{44}$ The problem in Richman, however, was that the Board was unable to impart such jurisdiction. No charge had been filed with the Board, and therefore it was unable to initiate section $10(j)$ proceedings for a temporary restraining order in the district court; similarly it could not render an order and petition the court of appeals for enforcement as provided by section $10(\mathrm{e})$. Therefore, the Court held that the state proceedings could not be enjoined.

Thus the rule which emerges from Richman is that neither the Board nor a private party may obtain an injunction against state proceedings on the ground that the NLRA preempts the dispute in favor of the Board and the federal courts, but that the Board may protect its jurisdiction only where it can impart jurisdiction to a federal court and where the state proceeding threatens the jurisdiction of that federal court. Without quarreling with Mr. Justice Frankfurter's finding of what Congress intended ${ }^{45}$ it is apparent that the Richman decision has two detrimental effects. First, in a limited number of cases - such as Richman - a party to a labor dispute will be able to circumvent the remedial procedures outlined in the NLRA. If no charge is filed with the Board, neither the Board nor a private party can protect the Board's prospective jurisdiction, and therefore, if the state court refuses to recognize a defense based on preemptionpossibly because preemption, while existing, may not be that clear-the state suit would have to run its course with the Supreme Court ultimately deciding that the state court lacked jurisdiction. The whole process could easily take a number of years and if, as in Richman, the issue is the propriety of the state court's injunction against union picketing, time rather than a judicial decree will have decided the dispute. ${ }^{46}$ Mr. Justice Frankfurter recognized this problem in Rich-

42 Id. at 515-16. It is interesting to note that two years later the Supreme Court found an implied exception where the United States, as a party, sought an injunction. Leiter Minerals, Inc. v. United States, 352 U.S. 220 (1957).

43348 U.S. at 517 .

44 Id. at 520 .

45 See generally Kochery, Conflict of Jurisdiction: 28 U.S.C. \$2283 and Exclusive Federal Jurisdiction, 4 BuFfaLo L. REv. 269 (1955).

46 Cox \& Bor, Cases on Labor Law 100 (6th ed. 1965). 
man, but declared that "insofar as a penumbral region must remain between state and federal authority . . . state litigation must, in view of $\S 2283$, be allowed to run its course . . . " 47

The second major problem arising out of the Richman decision is that it prescribes a technique for protecting the Board's jurisdiction whereby the arguments and the court's analysis must be made in terms of the federal court's jurisdiction. This approach distorts the issues and makes clearly reasoned opinions nearly impossible. For example, in Capital Service the problem was not that the state action frustrated the district court's power to issue a temporary restraining order; the real question was whether a party, having filed a charge with the Board, could frustrate the Board's jurisdiction by bringing the case before a state tribunal. The statement of the Supreme Court in Capital Service that the district court must have "unfettered" power to decide for or against the union is rather meaningless in that the district court granted precisely the same remedy as the state court; i.e., it enjoined the union picketing. Similarly, the issue that should have been considered in Schertaer was whether the state garnishment action so interfered with the Board's administrative procedures as effectively to frustrate the Board's jurisdiction over the awarding of back pay in the unfair labor practice dispute before it. Richman, however, by allowing a federal court to protect the Board's jurisdiction only where that protection can be justified in terms of the court's jurisdiction, led to an invocation of the "in aid of jurisdiction" exception where it was obviously inappropriate, and to a complete failure to justify adequately the injunction in terms of the Board's jurisdiction. Thus, Schertzer is one of the clearest cases demonstrating the distorting effects of Richman.

The deleterious effects of Richman demonstrate the need for an amendment to the NLRA. The amendment must enable the Board to seek an injunction against state proceedings which allegedly have the effect of frustrating the Board's prospective jurisdiction, as in Richman, or jurisdiction which the Board has already assumed, as in Capital Service and Schertzer. The amendment might read as follows:
A district court, upon application by the National Labor Relations Board, may restrain any party from instituting or prosecuting any proceeding in any state court, where the effect of that proceeding is the avoidance or frustration of the National Labor Relations Board's jurisdiction under this act. The filing of an unfair labor practice charge with the Board shall not be a prerequisite to the application for the re- straining order.

In relation to section 2283 , this amendment would permit injunctions to be granted as "expressly authorized by Act of Congress." 
Had the above amendment been in effect at the time of the Schertzer case, the lines of analysis would have been very different. The Board would have brought suit in a district court to enjoin the state proceedings, and the focus of the district court's inquiry-far from examining a threat to its own jurisdiction-would have been whether the state garnishment action so interfered with the Board's administrative procedures as to frustrate the relief which the Board would grant in the back-pay controversy. On the facts of Schertzer, three arguments could be advanced as to interference with Board procedures: compliance with the Board's order will be delayed until the conclusion of the state action; the Board's fiduciary role in enforcing back-pay awards would compel it to investigate and appraise the claims of the various creditors; and the Board would be enmeshed in controversy outside of the scope of the act. ${ }^{48}$

However, even if the NLRA were amended as suggested above, a district court should not issue an injunction in a case whose facts were like those in Schertzer. The argument that state garnishment would delay compliance with the Board's order is untenable in that it assumes that "compliance" with the Board's order results only when the amount of the award, in cash, is in the hands of the employee. The employee is not a ward of the Board, entitled to special consideration, and the Board has no interest in the garnishment suit. The Board's interest is satisfied when the employer gives up the economic benefit of the money in question, in favor of the employee, whether or not that sum immediately becomes subject to the claims of creditors.

The second and third arguments of the Board, that it would be compelled to investigate claims and to become enmeshed in controversies outside the scope of the NLRA, really reduce themselves to the contention that the limited time and resources of the Board and its personnel will be wasted on administrative necessities arising out of the state garnishment action to the detriment of Board activities in areas more vital to labor relations. Obviously, the Board will not have to weigh conflicting creditor claims; it need only require that the garnishor give the NLRB timely notice of the garnishment proceeding. Thereafter, a clerk will have to make a record of the garnishment action, and months or years later, upon final adjudication of the garnishment action, the back-pay award will have to be recorded as paid. It cannot be denied that this procedure is somewhat of a burden upon the Board's administrative processes. However, the proper test for the issuance of an injunction against a state court is not the administrative convenience of the Board. The test is whether the administrative burdens are so great as to frustrate the Board's

48 Brief for Petitioner, pp. 5-6, NLRB v. Schertzer, 360 F.2d 152 (2d Cir. 1966); cf. Phelps Dodge Corp. v. NLRB, 313 U.S. 177 (1941). 
ability to make a back-pay award in a dispute before it. It is inconceivable that the added demands on the Board's finances and time would be of such magnitude as to frustrate the Board's remedial processes. Considering the traditional attitude of noninterference with state courts, ${ }^{49}$ the adverse effects of the remedy sought seem heavily to outweigh the detriment to be avoided.

In conclusion, the Schertzer opinion cannot be justified under either of the grounds upon which it relied. Moreover, Schertaer demonstrates the distorting effect which Richman has had on cases where the Board has sought to protect its jurisdiction by petitioning the federal courts for an injunction against state proceeedings. By amending the National Labor Relations Act, however, Congress can remove this distortion and provide a basis for reasoned analysis in this area of labor relations.

49 See, e.g., Douglas v. City of Jeannette, 319 U.S. 157, 163 (1943); Toucey v. New York Life Ins. Co., 314 U.S. 118 (1941); Red Rock Cola Co. v. Red Rock Bottlers, Inc., 195 F.2d 406, 409 (5th Cir. 1952) (per curiam). 